\title{
Industrial Relations in Switzerland
}

\author{
F. J. L. Young*
}

Switzerland and the Scandinavian countries are noted for their low levels of industrial conflict. Thereafter the similarity between the two approaches to industrial relations becomes rather tenuous. The Swiss system of industrial relations is anything but centralised. It demonstrates what many outside observers might consider acute sensitivity to the preservation of individual freedom of choice. To some extent this may be explained in terms of Switzerland's unique form of direct democracy. At the same time, there is evidence that this multi cultural federation with complications of language and religion has achieved a large measure of consensus on the procedural aspects of industrial relations. In this respect, the peace agreement approach first introduced in 1937 has been described by an experienced Swiss mediator as "the main pillar of Swiss industrial peace". 1

\section{The Impact of Direct Democracy}

The role of government in the Swiss system of industrial relations is quite muted. At the same time it is clear that the system of direct democracy can make the actors sensitive to the views of citizens. Citizens have the right to launch an initiative (or proposal) for an amendment to the Constitution and the right to vote for rejection of any parliamentary bill. The referendum is commonly used to resolve issues of federal, cantonal or local concern. The Swiss Confederation is made up of 26 Cantons or administrative regions.

How this impacts upon industrial relations can be illustrated by reference to a proposal to introduce the 40 hour week. In 1976 a politically motivated initiative was launched to secure an immediate introduction of such a reduction in the work week. This was rejected in the subsequent referendum by a majority of four to one. Majority opinion is said to have considered the proposed change too rapid and likely to cause significant difficulties. Thereafter, trade unions commenced fostering their own initiative for a referendum on phased introduction of reduced working hours. Employers sought to negotiate the matter at enterprise level and government expressed the hope that the issue could be resolved by collective bargaining (thus permitting withdrawal of the initiative).

It would seem then that the actors are very much aware of the inherent cautiousness of the community. This may well reflect Switzerland's lack of natural resources. Despite its very high standard of living, the federation must import virtually all its raw materials, well over 60 percent of its food and in excess of 80 percent of its energy. The need to export to survive is ever present with the export of goods and services accounting for about 40 percent of GNP. ${ }^{2}$

* F.J.L. Young is Professor of Industrial Relations and Director of the Industrial Relations Centre at Victoria University of Wellington. This paper represents a substantial rewriting and updating of another paper, The Swiss Peace Agreement, originally prepared for the Nelson Trades Council's Industrial Relations Seminar in 1979. Wai Meng Foo acted as Research Assistant during the preparation of the paper.

1 Burckhardt, Lukas F. (1978) Industry-labor relations : industrial peace. In J. Murray Luck (ed), Modern Switzerland, Palo Alto, Society for the Protection of Science and Scholarship.

2 Crossland, Norman (1979) The everlasting league : A survey of Switzerland. Economist, London. 


\section{The Actors ${ }^{3}$}

\section{The Trade Unions}

Would the Swiss system of industrial relations have been more conflict prone if the trade unions were stronger? In comparison with the very high levels of organisation achieved by their counterparts in Scandinavia, Swiss trade unions cover around 35 percent of the country's labour force of nearly three million. How much weight one should attach to this comparatively low level of organisation is questionable. American trade unions currently seem hard pressed to maintain an average annual membership of 25 percent of the labour force. The American system of industrial relations experiences much higher levels of conflict than either Switzerland or the Scandinavian countries.

While Swiss trade unions are usually organised industrially, there is a variety of national bodies. Five national confederations (see Table I) encompass most trade unions and cater for a number of different political and religious beliefs.

Table I : Major Swiss Trade Union Confederations

\begin{tabular}{|l|c|c|}
\hline \multicolumn{1}{|c|}{ Grouping } & Affiliation & Membership \\
\hline $\begin{array}{l}\text { 1. Schweizerischer Gewerkschaftsbund } \\
\text { (SGB) }\end{array}$ & Social Democrat & 450,000 \\
2. Vereinigung Schweizerisher \\
$\begin{array}{l}\text { Angestelltenverbande (VSA) } \\
\text { 3. Christlichnationaler } \\
\text { Gewerkschaftsbund (CNG) }\end{array}$ & Independent & 150,000 \\
$\begin{array}{l}\text { 4. Landverband Frier } \\
\begin{array}{l}\text { Schweizer Arbeiter (LFSA) } \\
\text { Schweizerisher Verband } \\
\text { Evangelischer Arbeitnehmer (SVEA) }\end{array}\end{array}$ & Roman Catholic & 100,000 \\
\hline
\end{tabular}

Source: European Industrial Relations Review, 72, 1980.

Two smaller confederations cover bank employees and public servants. Too much significance, it would seem, should not be attached to this fragmentation of the movement at the national level. Unlike their Scandinavian counterparts, the confederations are not directly involved in collective bargaining. They concentrate on the provision of data required by affiliated unions for collective bargaining and on the training of full-time officials. They also lobby on behalf of their affiliates and members with the Federal Government.

More significant than the fragmentation of the movement nationally is the dominance of the pace-setting Metalworkers and Watchmakers Union. It comprises one third of the social democrat confederation (SGB) membership. Furthermore, its activities together with those of the graphic trades and the railway workers cover the most highly organised sectors of the labour force.

With industry-wide collective bargaining, the union presence in the workplace is made effective in two ways. The system of union delegates provides for the processing of individual grievances and the passing of information to and from the union hierarchy and grass roots membership. The system of works councils, usually established by collective agreement, gives elected union members certain rights of co-determination. 
It should be noted that the members of a works council are elected by the whole work force including members of management. The actual organisation and functions of each council are usually left to the discretion of its members. The type of co-determination matters dealt with by a council range from questions of social interest and welfare, through prior consultation on collective redundancies to receipt of regular information about the concern's prospects. It is also said that works councils exercise some leverage in the determination of basic rates of pay. Whilst Swiss collective agreements often leave the actual rate of pay for individual negotiation, the basic level is subject to discussion in the works council.

\section{Employer Organisations}

The major employer organisation in the private sector is the Zentralverband Schweizerischer Arbeitgeber - Organisationen (ZSAO). Individual companies are affiliated to ZSAO through industry or regional associations. It is estimated that ZSAO members employ well over a third of the labour force. Like the national trade union confederations ZSAO is not directly involved in collective bargaining. Unlike Scandinavian employer confederations, it has no power to fine or expel members to ensure compliance with employer policy. It concentrates on improving relations between members, providing them with data and acting as their lobbyist wth the Federal Government.

As far as the individual enterprise is concerned, the average organisation is said to be small to medium sized. This certainly permits face-to-face relationships encouraging good communications. It may also permit the survival of a measure of paternalism. The extent to which this colours industrial relations is hard to determine.

\section{The Nature and Scope of Collective Bargaining}

The legal regulation of collective bargaining is strictly limited in Switzerland. Neither the status of the parties to a collective agreement nor its contents are defined by law. The essential requirement is that parties wishing to conclude a collective agreement must first acquire legal personality. This makes any resulting collective agreement enforceable at law as at least one multinational company has found to its cost. ${ }^{4}$

The application of collective agreements is limited to trade union members in the firms signing the relevant document. Non-unionists may nonetheless be drawn into the web of an agreement in two ways. The employer may ask them to sign a declaration requesting the application of the terms of the agreement to themselves. This carries with it a requirement that they must pay a "solidarity contribution" to assist in meeting the cost of collective bargaining. On top of this, legislation does exist which provides for the extension of a collective agreement to unorganised parties within the same sector of an industry. The procedure can, however, only be implemented by mutual agreement. It is evidently very complex and rarely used.

With industrial unionism predominating, collective bargaining may occur at four levels: nationally, within the bounds of a canton,within a district, and within a company. A national agreement may be supplemented by others at the canton and/or district level. At these levels the signatories will be the appropriate employers' association and the trade union concerned. By way of contrast, company level negotiations will be limited to concerns not affiliated with ZSAO and local trade union officers.

\section{The Peace Agreement Approach}

The distinguishing feature of Swiss collective agreements is the peace obligation or peace agreement. This goes beyond the type of peace obligation found in many other systems of

4

Firestone is reported to have been fined well in excess of \$NZ 1.5 million in December 1979 by an arbitration tribunal for failure to follow a collective agreement when closing its plant in Pratteln and dismissing 505 workers on grounds of redundancy. The fine was paid to the union concerned for distribution to the workers involved. European industrial relations review (1980) 72 : p 5 . 
industrial relations. The Swiss distinguish between an absolute peace agreement and a relative one. Under an absolute peace agreement the parties bind themselves voluntarily not to strike or lockout under any circumstances during the currency of a collective agreement. Where a relative peace agreement is in effect, the parties simply abide by the legal obligation to abstain from stoppages over matters explicitly covered by their agreement. Surprisingly to an outsider, the absolute peace agreement is more common than the relative one. It is reported that about 66 percent of employees covered by collective agreements work under the absolute obligation. (Crossland 1979)

The peace agreement approach was pioneered in the engineering and metalworking industries in the late 1930s. ${ }^{5}$ It was associated with two strong personalities (the President of the Metalworkers and Watchmakers Union and the President of the Employers Association). Strong personalities alone, however, cannot explain the agreement's existence and success. Swiss history, attitudes and institutions were undoubtedly contributing factors. So too, according to the literature, was the rise of Nazi Germany, which led the community to close ranks. Whatever their relative influence, these factors created an environment which made possible the negotiation of the 1937 Peace Agreement. With minor amendments, this remained in effect until extensively renegotiated in the 1960s and 1970s.

The introduction to the 1937 agreement spelled out the principles governing the relationship between its signatories. The overall aim was to preserve industrial peace. The signatories were required to deal with each other in mutual good faith, settle disputes within the terms of the agreement and accept the absolute peace obligation. The application of these principles was then spelled out in eleven brief articles:

- Article 1 made provision for attempts to settle any conflict within the workplace as close as possible to where it occurred. The representative function of the trade unions was underlined by providing for the establishment of workers' committees in larger enterprises with committee members being chosen by the employees concerned.

- Article 2 covered deadlocked disputes involving specific matters of substance and the introduction of changes in working conditions or special agreements (see Article 4 below). These were to be referred to the executives of the signatories for negotiation
and settlement.

- Article 3 covered unforeseen problems arising during the currency of the agreement. It committed the parties to attempt to resolve such issues as they arose.

- Article 4 provided for the making of special agreements on specific matters (e.g. sickness insurance and bereavement pay). It was an open-ended provision.

- Articles 5 and 6 provided for the conciliation of unsettled disputes involving general wage modifications, or special agreements or the interpretation of the Peace Agreement itself.

- Article 7 covered situations in which a conciliation board was unable to effect a settlement. It provided for such a board to pronounce an arbitration award subject to the signatories previously indicating their willingness to accept such a determination.

- Article 8 provided for the reference of deadlocked disputes involving a general wage modification or special agreement to be referred to a special arbitration board for settlement. This procedure was limited to exceptional circumstances where no alternative settlement could be devised and then only upon application of one of the parties
involved. - Article 9 specifically excluded questions of union membership or non-membership from
the agreement.

5

Haberlin, Hermann (1967) The Peace Agreement of July 19th 1937. In Swiss pioneers of economics and technology, Zurich, Association for Historical Research in Economics. 
- Article 10 committed the signatories to ensuring that their members observed the agreement. Each party was required to deposit SFr 250,000 in the National Bank as caution money. In the event of a violation of the agreement, a specially appointed court of arbitration could impose a conventional fine upon either party.

- Article 11 spelled out the period of validity of the agreement.

The essentially procedural nature of the 1937 Peace Agreement is obvious. Its apparent lack of concern for wage rates is notable. Indeed the agreement actually indicated that pay rates were to continue "to be regulated through the individual service agreement" (a custom in this industry and others). Whether this reflects the relative bargaining power of the signatories or the individualism of the average Swiss is an interesting point.

\section{Arbeitsfrieden}

Brief and limited in scope though it was, the original Peace Agreement seems to have created an atmosphere in which the Employers Association was able to persuade its members of the benefits of collective bargaining. Moreover, as others emulated the approach, the practice spread. The Swiss boast of Arbeitsfrieden (or industrial peace) is certainly upheld by available data on the impact of strikes since World War II. The following graphs update information which originally appeared in the London Economist of 3 February 1979:

Figure 1 : Selected Data on Strikes in Switzerland, 1970 - 1979

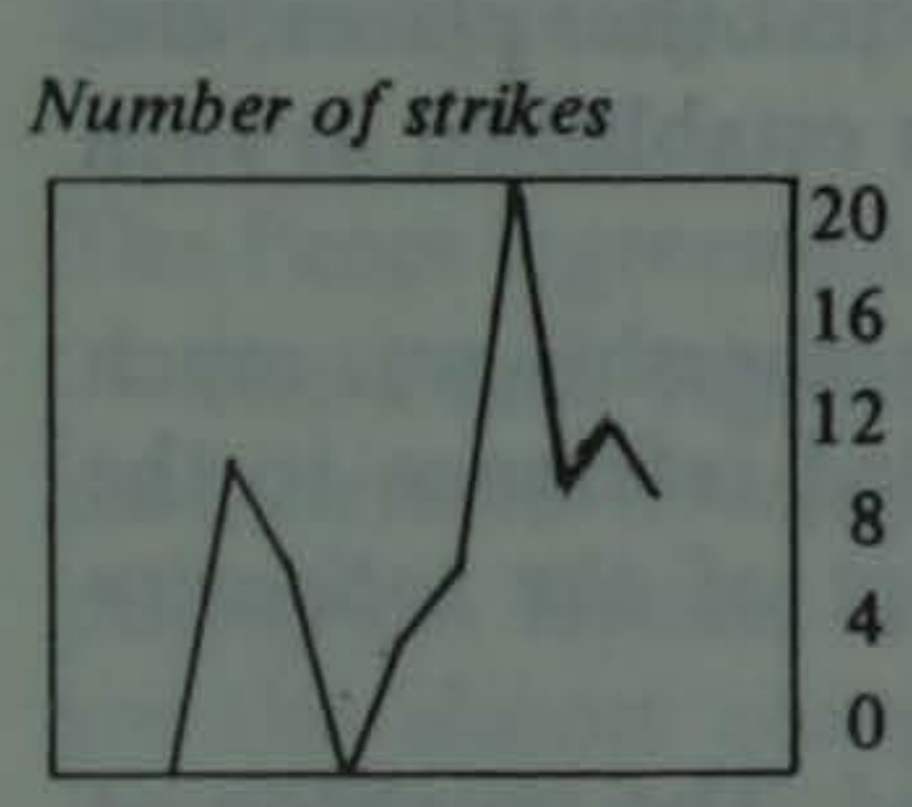

19707274767880

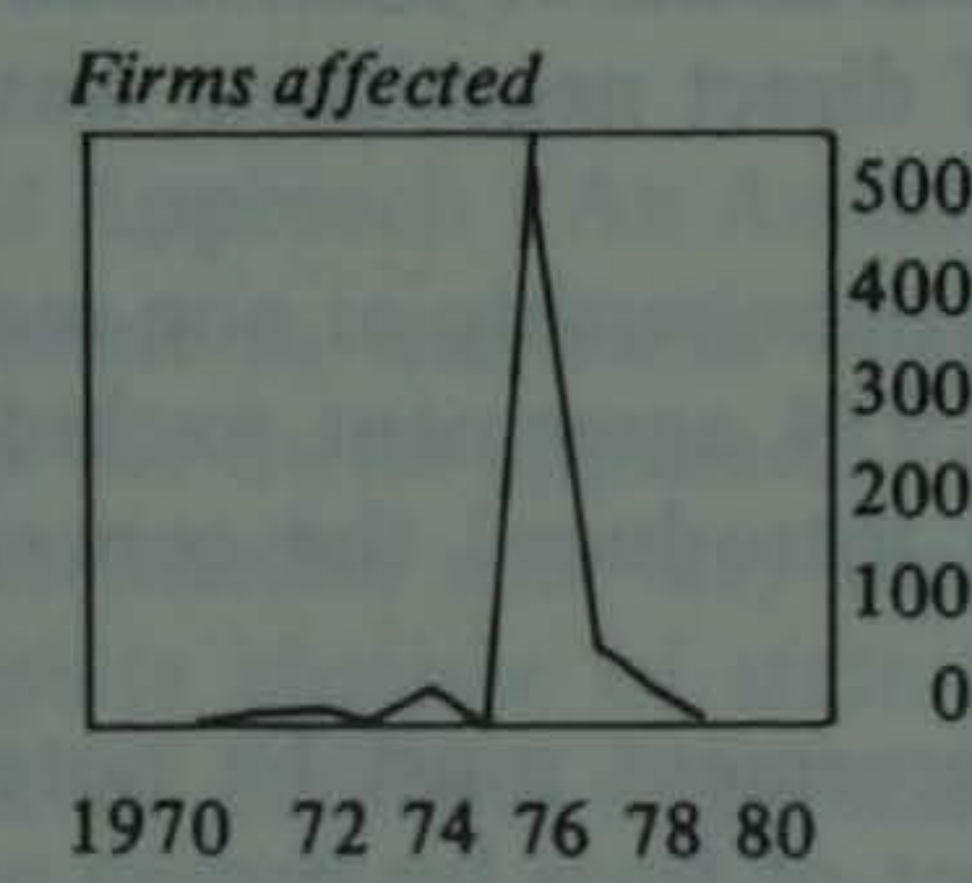

19707274767880

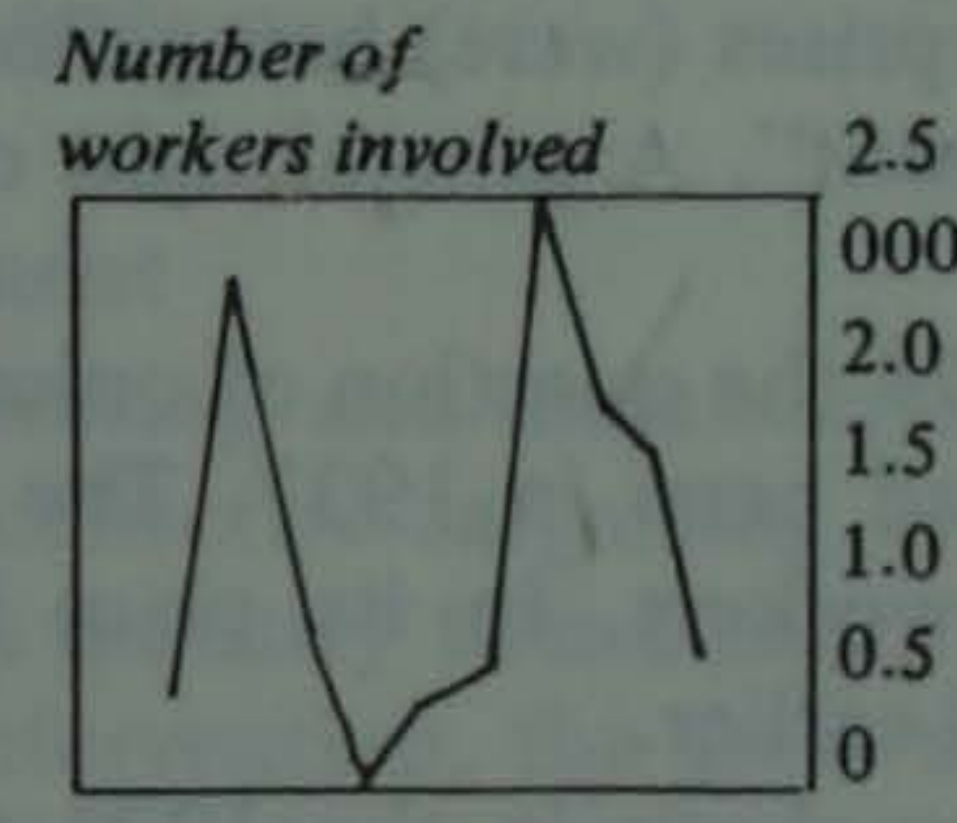

19707274767889

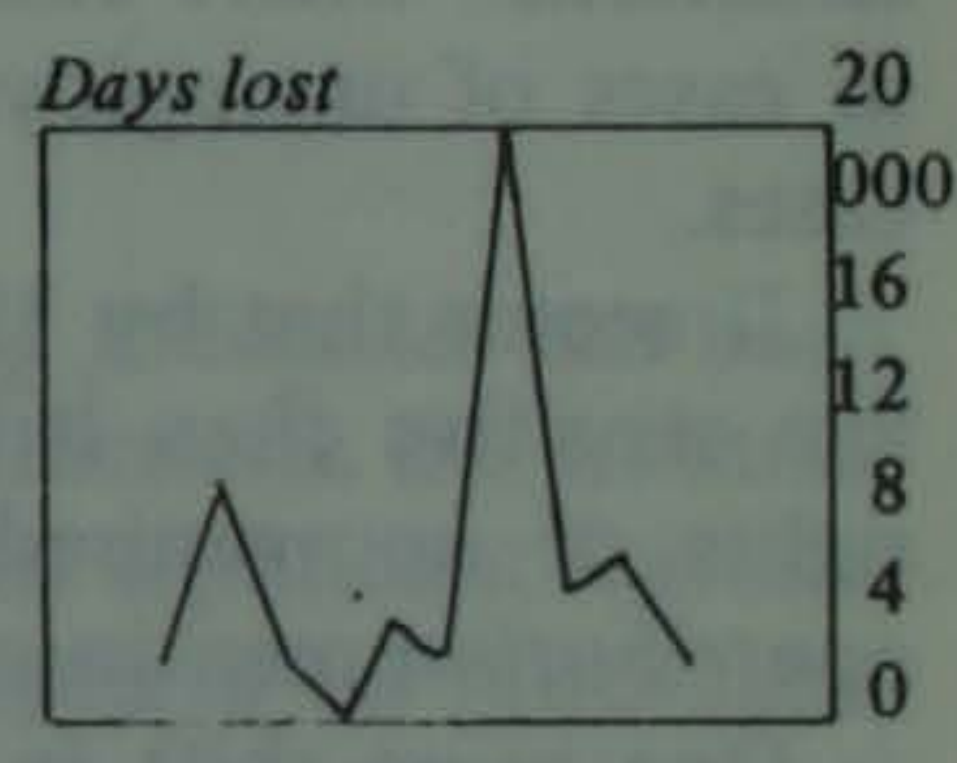

19707274767880

Source: L'Association Patronale Suisse des Constructeurs de Machines et Industriels en Metallurgie.

The data cited above indicate that 1976 was a "bad" year for strikes by Swiss standards. That year saw 20 stoppages involving less than 2,500 workers in some 500 firms. Working days lost in these conflicts amounted to almost 20,000 , an insignificant fraction of the time worked by a labour force of 2.7 million persons. The equivalent figures for New Zealand in 1976 were 487 stoppages involving 201,085 workers in an unspecified number of concerns; working days lost amounted to 488,411 with a labour force of about 1.27 million. While international comparisons of strikes are notoriously unreliable (because of differences in data base), this particular contrast is too gross to ignore. Interested readers who wish to examine data on strikes in Switzerland over a longer period are referred to the Appendix at the end of this paper.

\section{The Peace Agreement of 1974}

It is clearly significant that the peace agreement approach was not abandoned in the hardening economic climate of the 1970s. In the engineering and metalworking industries, the new Peace Agreement of 1974 , suggests that the parties saw considerable merit in 
expanding this approach to collective bargaining. It is not proposed to analyse this new agreement in detail here. Certain matters must, however, be highlighted to point to significant shifts in approach.

The preservation of industrial peace was the central purpose of the original agreement of 1937. The document negotiated in 1974 had much wider aims and scope. The establishment of mutual rights and obligations in employment matters, the promotion of collaboration within enterprises and the resolution of important differences of opinion and disputes now took pride of precedence.

The 1974 agreement saw the extension of workers' committees (works councils) to all enterprises not simply larger concerns. The function of such a committee was declared to be "defending the interests of all of the employees under the agreement against the employer and ... taking care of the problems connected with the application of the agreement in the enterprise".

A restructuring of the provisions governing conciliation and arbitration was undertaken in the new agreement. Should conciliation become deadlocked, the conciliation board could now proceed immediately to arbitration. The award of the board was to be binding. Furthermore, this procedure would apply in all instances and not, as previously, only in exceptional circumstances.

The 1974 agreement also reflected increased concern for resolving disputes at the earlier stages. Should workplace negotiations reach an impasse, the parties were now entitled to call for assistance from the signatories to the agreement before the matter was referred to their executives. This provision encompassed changes in wages, working hours and methods of payment as well as the interpretation and application of the whole agreement.

An additional special agreement was included in the 1974 settlement. This covered situations "where enterprises (were) being closed down or transferred to other places, and in cases of unemployment". A general right of direct negotiation was established in such cases.

It seems that by 1974 the question of union membership or non-membership was much less sensitive than it had been in 1937. The 1974 agreement excluded reference to the rights of unorganised workers. In its place it introduced the concept of the solidarity contribution mentioned earlier.

One more shift in emphasis in the 1974 agreement must be noted. The provision of caution money as a security against the payment of fines for breach of the agreement was eliminated. This at least suggests the development of a high degree of confidence that all parties would live up to their obligations under the agreement.

At this point, one may ask why the parties decided to extend the scope of the agreement in the 1974 negotiations. Acceptance of the benefits of collective bargaining by employers has already been noted. That, however, does not offer an explanation of why trade unions accepted the continuation of the absolute peace obligation in the hardening economic climate of the 1970s. Here several factors were probably influential. The improved procedures for conciliation and arbitration mentioned above were linked with a provision to deal with unanticipated events likely to erode the agreement (essentially the American concept of "the continuous obligation to bargain").

Another factor influencing trade union attitudes may well have been experience with the joint administration and funding of the so-called Partnership Fund. This fund was established in 1969 to finance industrial relations and vocational training. How far this venture illustrates the Swiss tradition of group activity within one's own community and how far it represents mutual support to ensure survival are interesting questions. The engineering and metalworking industry is unusually sensitive to international trade. About two-thirds of the production of the metal and machinery factories and almost all the output of watch-making concerns are exported. Without the experience of the fund and the special agreement on the closure of enterprises, the peace agreement approach could well 
have run into very, heavy weather with the coming of the electronic watch. Between 1969 and 1979 , foreign competition compelled the watch-making sector of the industry to rationalise. This resulted in its labour force being cut from 85,000 to 50,000 . (Crossland 1979)

\section{The Special Agreement on Closure of Enterprises}

With this background it is possible to examine the special agreement on the closure of enterprises more closely. The decision to close an enterprise is said to rest with "its own leadership". The action, however, must be tempered with concern to avoid or alleviate the hardship involved. Notification of a proposed closure must be given to the workers' committee involved and to the signatories of the Peace Agreement without delay. It must include reasons for the closure, the plan and timing involved. The signatories to the Peace Agreement may intervene at this point should they be requested to do so by the workers' committee.

In the event of the closure of an enterprise, the employer must give due notice, ensure that wages, fringe benefits and other entitlements are paid and transfer pension rights to an employee's next workplace. The latter obligation is linked with requirements which can be placed under the general heading of "active employment policy". For example, transfers to other parts of the enterprise in the event of a partial shutdown, retraining, assistance in job search, relocation allowances and early retirement.

Baldly stated, these arrangements could be misconstrued to give a rosy picture of the painful process of adjustment to industrial change. The arrangements certainly seem to have eased the process of adjustment, but it has certainly not taken place without friction. It is reported that 15,000 of the nearly 20,000 working days lost in stoppages in 1976 resulted from one stoppage at one factory where the procedures of this special agreement had been poorly implemented. (Burckhardt 1978)

\section{The Peace Agreement Approach : An Assessment}

The Peace Agreement in the Swiss engineering and metalworking industries has been used here to develop the Swiss approach to collective bargaining. It illustrates the essential principles. Details nonetheless will vary from industry to industry. The significant features are the almost complete absence of state intervention, the great emphasis on procedural matters and the lack of detailed wage schedules. In some instances, wages are entirely a matter between the individual employee and his/her employer; in others, minimum rates are specified for broad categories of skill but the actual rate paid still remains subject to individual negotiation. How far these rather unusual features result from factors unique to Switzerland is hard for outsiders to determine. The aversion of the average Swiss to governmental regulation of his or her affairs is almost proverbial. At the same time, the system of direct democracy may well predispose Swiss citizens to favour a strongly procedural but voluntary approach to the resolution of industrial conflict. Both influences could co-exist with individual negotiation of remuneration (although it must be pointed out that such an arrangement for determining salaries also exists in white collar employment in Sweden).

\section{Individual Employment Rights}

It has already been pointed out that the role of government is quite muted in the Swiss system of industrial relations. As far as individual employment rights are concerned the Constitution provides certain guarantees and the Code of Obligations establishes other rights. $^{6}$ The overall impression remains that Switzerland approaches these matters with great caution. The case of equal pay and equal opportunity is illustrative.

Currently equal pay for equal work is limited to employees of the Federal Government, which has ratified the relevant ILO Convention. Article 4 of the Swiss Constitution states

6 European industrial relations review (1980) $73:$ p 4 and $81:$ pp $15-16$ 
that "All Swiss citizens are equal before the law. In Switzerland there shall be no privileges of place, birth, person or family." Despite this, difficulties are being experienced in providing for a constitutional amendment to ensure equal rights and opportunities. In the meanwhile, women's rates of pay seem to average about 75 percent of the equivalent male rates and a large proportion of the female labour force has had no vocational training.

The theme of caution continues when one examines rights flowing from the Code of Obligations. It outlaws the closed shop (both pre-entry and post-entry) and declares that union membership must not be a consideration in selection or training. To some extent, the solidarity contribution mentioned earlier must be seen as a means of overcoming these "negative rights of association".

Once employed, a Swiss worker is entitled to a limited range of statutory rights. Wages and salaries must be paid at monthly intervals unless arrangements exist for a shorter pay period. Pay must continue during involuntary absence upon completion of three months service (the actual period of benefit accumulates with service but varies with the canton in which the individual works). In certain circumstances, such as power cuts, pay must continue even if work is not available. A minimum of two weeks paid annual leave is stipulated with three weeks for persons under 19; these entitlements may, however, be increased to three and four weeks respectively by cantonal statute. No provisions exist for certain other benefits found in other industrialised countries (for example, educational leave or paid time off for trade union activities). It should be noted that these issues are nevertheless often covered in collective agreements.

Whilst Swiss law requires that proper notice be given before dismissal, it does not cover the concept of "unfair" dismissal or the matter of victimisation. The employer is placed under no legal obligation to give reason for the action whether the case involves summary dismissal or dismissal after due notice. Required notice of dismissal varies from seven calendar days for probationary employees to three months for persons with at least nine years' service. Long service employees aged 50 with 20 years' service with the same employer also qualify for additional severance pay in the event of dismissal.

\section{A Particular View of Reality}

The acceptability and effectiveness of the Swiss system of industrial relations seems to rest on a particular view of reality which is widely held throughout the Confederation. An outsider may find it hard to decide whether this view of reality is based on realistic pragmatism or inherent conservatism. Those favouring the pragmatic explanation will point to levels of employment in the late 1970s. Despite the current recession, Switzerland still had virtually full employment. Relatively high wages were being paid to meet the high cost of living. In 1979 the wages of semi-skilled and skilled industrial workers were reported to range between $\$ N Z 17,000$ and $\$ N Z 21,000$. Cynics favouring the explanation of inherent conservatism will stress other matters. Full employment seems to have been maintained by sending home over 220,000 foreign workers in the mid-seventies. Unequal pay for women was commonplace. Annual pay increases had been held right down although linked to cost of living adjustments. The reason for trade unions not pressing for wage increases over two percent per annum was reported to be acceptance of the fact that "the appreciation of the external value of the franc (had) been cutting into profit margins". (Crossland 1979)

Whatever the explanation for the widespread view of reality, some two-thirds of the country's labour force has chosen to work under absolute peace agreements. The rest accept the legal requirement of a relative peace agreement. Furthermore, polls of public opinion indicate that the peace agreement approach continues to be held in high public esteem. To this must be added an attitude articulated by the Metalworkers and Watchmakers Union:

The man at the workbench is concerned with other social problems than his manager. Tensions cannot be abolished, but only mediated. An agreement, however, is only possible if there are no positions of absolute power over 
human beings. This is the reason we need free groups who act as rivals. The unions are such a legislative force. They function only in a democracy, i.e. in a political system based on synthesis and co-operation of opposite forces which also have common concerns. Therefore we cannot live without conflicts, and we should have the courage to admit this openly. Only we must care that these encounters are carried out as much as possible in a spirit of tolerance. ${ }^{7}$

What people believe may be quite as important (if not more important) than what they experience in fashioning a country's system of industrial relations.

\section{Appendix}

Strikes in Switzerland, 1950 - 1979

\begin{tabular}{|c|c|c|c|c|c|}
\hline & ear & $\begin{array}{l}\text { Number of } \\
\text { strikes }\end{array}$ & Firms affected & $\begin{array}{c}\text { Number of } \\
\text { workers involved }\end{array}$ & Days lost \\
\hline 1950 & $\ldots \ldots$ & 6 & 68 & 288 & 5,447 \\
\hline 1951 & $\ldots \ldots$ & 8 & 70 & 985 & 8,469 \\
\hline 1952 & $\ldots \ldots$ & 8 & 47 & 1,207 & 11,588 \\
\hline 1953 & $\ldots \ldots$ & 6 & 513 & 2,079 & 61,124 \\
\hline 1954 & $\ldots \ldots$ & 6 & 283 & 2,997 & 25,963 \\
\hline 1955 & $\ldots \ldots$ & 4 & 4 & 430 & 1,036 \\
\hline 1956 & $\ldots$ & 5 & 15 & 286 & 1,439 \\
\hline 1957 & $\ldots \ldots$ & 2 & 3 & 71 & 740 \\
\hline 1958 & $\ldots$ & 3 & 3 & 815 & 2,127 \\
\hline 1959 & $\ldots \ldots$ & 4 & 15 & 126 & 1,987 \\
\hline 1960 & $\ldots$ & 8 & 20 & 214 & 1,016 \\
\hline 1961 & $\ldots \ldots$ & - & - & - & - \\
\hline 1962 & $\cdots$ & 2 & 2 & 163 & 1,386 \\
\hline 1963 & $\ldots \ldots$ & 4 & 73 & 1,120 & 70,698 \\
\hline 1964 & $\ldots$ & 1 & 4 & 350 & 4,550 \\
\hline 1965 & $\ldots \ldots$ & 2 & 2 & 23 & 163 \\
\hline 1966 & $\ldots \ldots$ & 2 & 2 & 38 & 62 \\
\hline 1967 & $\ldots \ldots$ & 1 & 1 & 65 & 1,690 \\
\hline 1968 & $\ldots$ & 1 & 1 & 70 & 1,785 \\
\hline 1969 & $\ldots \ldots$ & 1 & 1 & 33 & 231 \\
\hline 1970 & .s. . . . & 3 & 3 & 320 & 2,623 \\
\hline 1971 & $\ldots$ & 11 & 13 & 2,267 & 7,491 \\
\hline 1972 & $\cdots$ & 5 & 5 & 526 & 2,002 \\
\hline 1973 & $\ldots$ & - & - & - & - \\
\hline 1974 & $\ldots$ & 3 & 34 & 299 & 2,777 \\
\hline 1975 & $\ldots$ & 6 & 6 & 323 & 1,733 \\
\hline 1976 & $\ldots$ & 19 & 492 & 2,395 & 19,586 \\
\hline 1977 & $\ldots \ldots$ & 9 & 54 & 1,380 & 4,649 \\
\hline 1978 & $\ldots$ & 10 & 13 & 1,240 & 5,317 \\
\hline 1979 & $\ldots \ldots$ & 8 & 8 & 463 & 2,331 \\
\hline
\end{tabular}

Source: L'Association Patronale Suisse des Constructeurs de Machines et Industriels en Metallurgie.

7 Swiss Metalworkers and Watchmakers Union (1976) Das Profil einer Gewerkschaft, Bern, quoted by Burckhardt in the article already cited. 